\title{
REASSESSING THE RADIOCARBON CHRONOLOGY OF THE MAIORO SITE (R13/1): NORTHERN WAIKATO, NEW ZEALAND
}

\author{
ROD WALLACE and ROGER C. GREEN \\ The University of Auckland
}

The late Aileen Fox, while at the Auckland War Memorial Museum, wrote up excavations carried out in 1965-66 by Roger Green and members of the Auckland University Archaeological Society at the Maioro site (R13/1) (Fox and Green 1982). The site is located at the southern end of the 100-200 metre high undulating sandstone ridge that extends south from the South Manukau Heads to the Waikato River mouth. The site is about $4 \mathrm{~km}$ north of the Waikato River on a high knoll about a kilometre from the coast. It is a small, terraced settlement with pit features that lacked the obvious earthwork defences of a $p \bar{a}$. It was chosen as part of Green's ongoing study of open settlements presumed to relate to the mid and late period of New Zealand prehistory.

Based partially on stratigraphy and partially on ${ }^{14} \mathrm{C}$ determinations, three phases of occupation were identified (Green 1983). In Phase 1 the site consisted of a series of subterranean storage pits which extended along the top of a ridge and knoll. In Phase 2, occupation focused on the knoll alone with the much more confined terraced space now enclosed by scarps topped by a well-defined perimeter palisade, indicating it was now a fortified $p \bar{a}$. In Phase 3 these defences were rebuilt and strengthened.

The initial radiocarbon determinations reported by Green (1983) implied occupation of the site may have begun as early as the late 12th AD and continued until the 17th century. The occurrence of a specialised agricultural settlement as early as the 12th century was unexpected and Green (1983: 109) expressed some reservations as to the validity of the earlier dates. He was well aware that there could be sources of analytical bias (e.g., potential for inbuilt age in the charcoal). Over the last two decades it has become increasingly obvious that the dating of this site needed re-examination. The reasons are several but mainly centre on the reliability of the ${ }^{14} \mathrm{C}$ determinations.

First, when the initial radiocarbon samples were run, the calibration of ${ }^{14} \mathrm{C}$ determinations to yield secular ages was still in its infancy. Neither the atmospheric corrections, now routinely applied to terrestrial samples, nor local or regional offsets, now used in calculating secular ages for marine shellfish whose diet incorporates older carbon from the Ocean Marine Reservoir, 
were developed. Second, the dates on wood charcoal were processed without the species involved having been identified. The extent to which such ${ }^{14} \mathrm{C}$ determinations might relate to the age of the trees rather than the cultural events concerned was not fully appreciated at the time. Finally, when Maioro was dated, Accelerator Mass Spectrometry (AMS) technology, which allows for dating of tiny samples, had yet to be fully implemented in New Zealand. This method is now routinely available and allows re-dating of sites using very small charcoal samples.

Fortunately, at the time the original dates were run the larger charcoal samples were divided with one part being retained as a backup and archived at the Rafter Radiocarbon Laboratory. Three backup samples were available, two from Phase 2 and one from Phase 3. Garry Law requested their return and passed these to Green, who retained them for more than two decades. His intention was to have the charcoal identified to assess their potential for inbuilt age in order to attempt to resolve what he saw as a questionable dating outcome.

\section{RESULTS}

\section{Wood charcoal identifications}

In 2005 Wallace made a preliminary inspection of these charcoal samples which revealed they were dominated by Püriri (Vitex lucens), a large, long lived tree whose charcoal is not normally recommended for dating as it has the potential for a high inbuilt age. On reviewing these results in early 2006, Green asked Wallace to extract short-lived species from one of the samples with a view to their dating by AMS. The objective here was to obtain new age estimates for the Phase 2 occupation and resolve outstanding questions about the accuracy of the original determinations. Wallace reported the following results.

NZ6276 - Phase 3 - Maioro [3] AU Cat\#2035 - Run No. R09572/3

Püriri (Vitex lucens) - 100\%

No small diameter material was present and all charcoal pieces appear to have come from the same, possibly large, piece of burnt wood. As dating material this charcoal is unsatisfactory as it has the potential for considerable inbuilt age.

NZ 6274 - Phase 2 - Maioro [1] AU Cat\#2002 - Run No. R09572/1 Pūriri-100\%

Charcoal pieces had brown, charred ends indicating they originated as the burnt off end of a post or other large piece of timber, the unburned part of which had decayed away. As dating material it was unsatisfactory, as it has the potential for significant inbuilt age. 
NZ 6277 - Phase 2 - Maioro [4] AU Cat\#2051 - Run No. R09572/4

Pūriri-95\%

Tōtara (Podocarpus totara) $-3 \%$

Coprosma sp. $-1 \%$

Hebe sp. $-1 \%$

Ninety-five percent of the charcoal was from Püriri, a large, long lived, tree that has the potential for significant inbuilt age. It is significant that Tötara, a species that can live to great age, was also present in this sample. A 0.17 gram sub-sample of short lived Coprosma and Hebe charcoal was separated out as an accelerator dating sample. This was subsequently forwarded to the University of Waikato and processed under their AMS protocols as WK19214.

\section{THE ORIGINAL MAIORO CHRONOLOGY}

Rather than simply rejecting the original dates as deriving from unidentified charcoal that may have come from tree species with significant inbuilt age, we assess each sample's stratigraphic position in a way which allows some useful information to be extracted.

\section{Phase 1}

Phase 1 consisted of a series of subterranean storage pits along the top of a ridge and knoll. Davidson et al. (2007: 18-91), in their review of storage pit types in New Zealand sites, concluded that they probably functioned as community stores for sweet potato. The sandy loam soils found in the dune swales around the Maioro site, when planted in kümara, would have been productive for at least for a year or two. During Phase 1 the stored crop apparently did not require defensive constructions to protect either it or the occupants of the site from unwanted predation by others in the region.

NZ6278 (see Figure 1 below) was recovered from a Phase 2 occupation context. On the basis of the sample's early date, Green (1983: 108-9) suggested it may have been Phase 1 charcoal eroded from a steep embankment and redeposited on the Phase 2 terrace below (see Green 1983: Fig. 1). However, Green (1983: 108) also stated that the unexpectedly early date for the Phase 2 charcoal may have been owing to it having inbuilt age.

NZ6275, in contrast, has an unambiguous Phase 1 context. It came from a very deep posthole over $180 \mathrm{~mm}$ across in its greatest dimension with a roughly square post mold indicating it had held a dressed wooden timber. It was interpreted that this post had supported a storage hut (pataka or whata) and that a slanting posthole a short distance away had held a ladder that provided access to it (Fox and Green 1982: 65, Green 1983: 108). The charcoal was clearly from a large timber cut from a substantial tree trunk, which implies a potential for significant inbuilt age for this dating sample. 


\section{Phase 2}

During Phase 2 occupation focused on the knoll alone with the much more confined space now defended by earthwork scarps and a well-defined perimeter palisade. There are now four dates for Phase 2, three of which have been published previously (Green 1983), and a new AMS date (WK19214) that is reported here [CRA382 $\left.\pm 32 \mathrm{BP}, \delta^{13} \mathrm{C}-26.7 \pm 0.2\right]$.

Sample NZ6279 was composed of pipi (Paphies australis) shells recovered from a Phase 1 pit on the ridge east of the knoll that the occupants of Phase 2 had used as a convenient place to dump their rubbish. It was calibrated using a $\Delta \mathrm{R}$ value of $37 \pm 39$, as suggested for shells of this species deriving from the west coast of the North Island of New Zealand (Petchey et al. 2008: 248).

Sample NZ6277 was from a patch of charcoal associated with burned posts on edge of the knoll just inside the Phase 3 palisade line. The field notes (Fox and Green 1982: 64, Green 1983: 110) state that "from the stratigraphic sequence and the amount of wood, much of it partially charred and totara from its look, the post butts were burned off level to the ground and then the area renewed by a buildup of clay". This overlying clay layer was associated with construction of the Phase 3 palisades and thus sample NZ6277 is clearly from a Phase 2 context (making its attribution to Phase 3 in the New Zealand Radiocarbon Database [http://www.waikato.ac.nz/nzcd/] an error). Identification of the retained charcoal from this sample revealed it was a mixture of Püriri, Tötara, Coprosma and Hebe, clearly demonstrating it was mixed occupation material rather than the single burnt Tōtara post butt suggested in Green's field notes.

WK19214 was derived solely from tiny pieces of Coprosma and Hebe charcoal extracted from the retained portion of NZ6277.

The final dated sample from Phase 2 (NZ6274) was from a single small diameter posthole in the Square F9 baulk that was stratigraphically coincident with the burned off post butts that provided the other Phase 2 charcoal samples.

\section{Phase 3}

Sample NZ6276 was only tentatively attributed to Phase 3. It came from the fill of one of three postholes near to the palisade fence in the southwest corner of square F5, two of which belong to Phase 3 and one to Phase 2. On the basis of the sample's slightly younger date Green (1983: 110-11) concluded that it came from the Phase 3 posthole nearest to the southwest corner of this square. It was suggested this substantial timber upright supported a raised open platform, on top of which dried fern root or other foods could be stored away from predation by rats as illustrated in early to mid-19th century literature on Māori settlements. All the charcoal was Pūriri, most with brown ends 
indicating they originated as the burned off end of a single piece of timber, the unburned part of which had since decayed away.

It should be noted here that in two cases Green (1983) drew on the outcome of ${ }^{14} \mathrm{C}$ dating to assign samples to occupation phases.

\section{REVISION OF THE MAIORO SEQUENCE}

\section{The Phase 2 and 3 dates}

As can be seen on Figure 1, the Phase 2 and 3 samples form a consistent series that overlap at one standard deviation $(1 \sigma)$. This suggests less than 50 years had elapsed between these two occupations and an age centred on the 16th century is well-supported by these results. This conforms well to the wider New Zealand pattern whereby fortified sites or $p \bar{a}$ only occur from the 15th century onwards (Schmidt 1996: 446).

Although three of the above samples were run on charcoal from the large and long lived Püriri tree, they show no evidence of more than 50 years of inbuilt age. Because the issue of inbuilt age will arise again when we discuss the Phase 1 dates, it is important to try and understand why this should be so. To do this we need to examine both the natural history of the Püriri tree and the uses to which its timber was put at Maioro. Püriri is a large, long-lived tree of northern North Island strongly associated with the fertile soils sought out by both Māori and early European settlers (Dijkgraaf 1994, Dykgraaf 1992). Though lowland forests where it originally grew were progressively cleared, Püriri has, unlike most other large trees, a remarkable ability to survive forest clearance and to re-grow from fallen trunks and roots (Dijkgraaf 1994: 111-13). At European arrival Püriri was common in coastal areas even where bracken fern and scrub dominated the vegetation and, despite over a century of modern farming, it remains a common feature of present day landscapes. Wallace has identified Püriri charcoal from about one hundred assemblages from Maori archaeological sites in the northern North Island, where it is both abundant and is often the only large tree in samples otherwise dominated by short lived woody species.

Püriri appears to have supplied much of the timber for posts and palisades during Phases 2 and 3 at Maioro. As dry Püriri heartwood has been known to chip even modern steel axe blades, it seems likely that these posts were normally cut from green wood. The secondary trunks of Püriri grow to the size required for posts in at least 50 years, therefore yielding a mean potential inbuilt age of less than 50 years. Despite not meeting the current practice of selecting only short lived species for dating purposes (McFadgen 1982) this is almost certainly why the Maioro Püriri charcoal appears to have supplied reliable dates. 
80 Reassessing the Radiocarbon Chronology of the Maioro Site

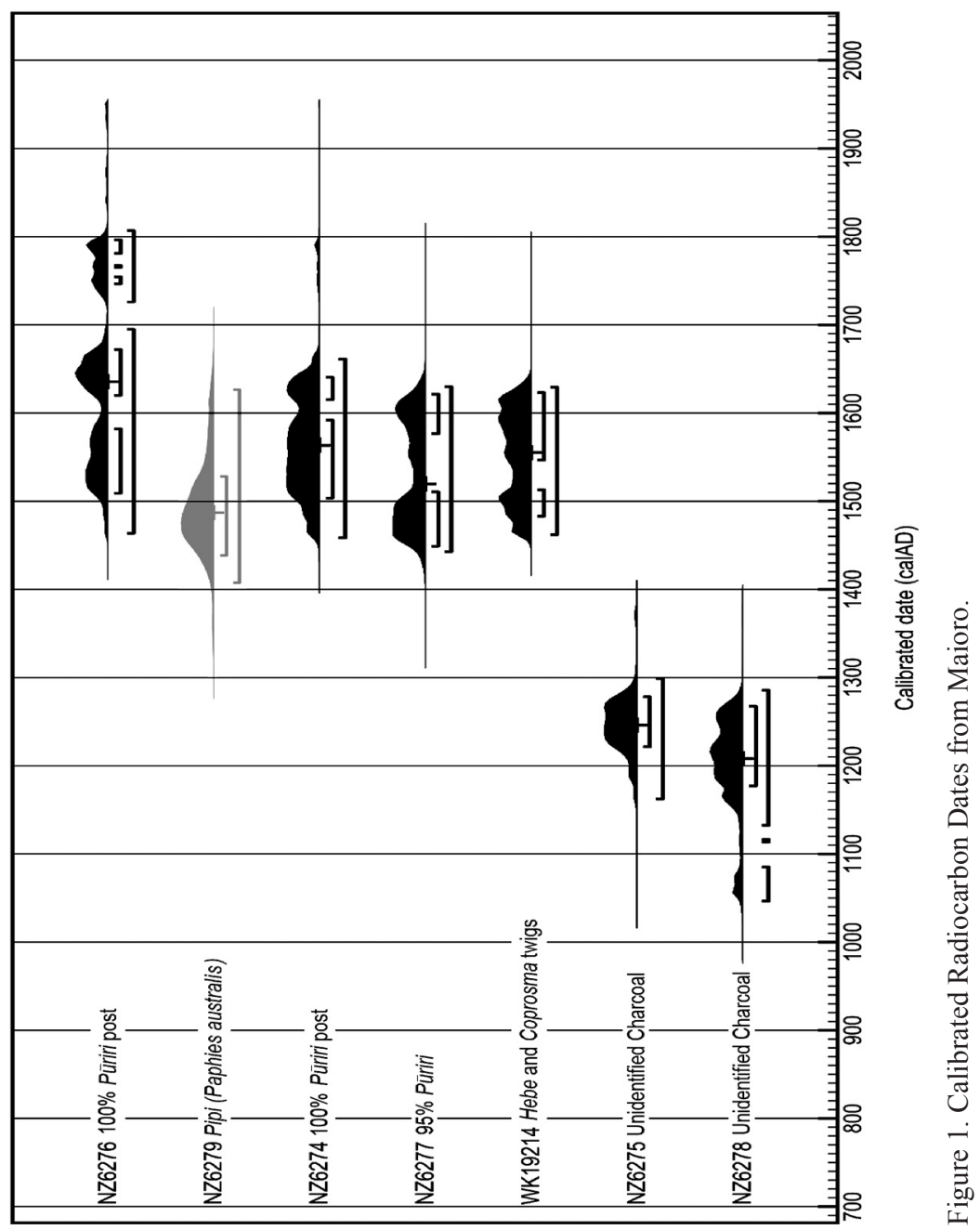


The Phase 1 dates

At face value the Phase 1 dates (NZ6278 and NZ6275) suggest a gap of up to 300 years between the initial occupation of the site and the construction of the later defences. An Archaic or Moa Hunter era date for a pit and terrace site that had subsequently been modified to become a $p \bar{a}$ was unexpected since a general review of the evidence suggests this site type dates from the 15th century onwards (Schmidt 1996). Furthermore, no evidence was recovered during excavation that pointed to any significant time gap between Phases 1 and 2 (Fox and Green 1982: 76). For these reasons Green (1983: 108) at the time proposed the alternative explanation, specifically that the Phase 1 dating sample came from wood that had grown several centuries before it was burned. We now know that both Phase 1 samples were remains of posts made from substantial tree trunks and, in retrospect, Green acknowledged it was naive to date charred fragments of such large timbers of unknown species.

The unexpectedly early ${ }^{14} \mathrm{C}$ determinations of Phase 1 could contain several hundred years of inbuilt age only if the samples derived from large, slow growing forest trees such as Tötara, Matai or Kauri. These species can contain wood with hundreds of years of inbuilt age and, moreover, it has long been demonstrated that logs of such species have durable timber which can persist for generations in many New Zealand landscapes (Molloy et al. 1963: 69). If the first inhabitants of Maioro cleared primary forest to plant their crops such timber would have been readily available. Wallace has identified many charcoal assemblages where the use of such sub-fossil wood by pre-European Māori is strongly suggested. These are dominated by scrub and shrub species yet contain charcoal of a few large forest trees, such as Tötara, Matai and Kauri, but contain none of the other tree species that would have accompanied them in a living forest community. These results seem to indicate most pre-European Māori settlements in the northern North Island were set in fern and scrub vegetation; old stumps and logs continued to supply timber and firewood long after the forests had been cleared.

In sum, the overall evidence suggests the two 12-13th century dates obtained from unidentified charcoal samples may well have been biased by inbuilt age and, consequently, their ${ }^{14} \mathrm{C}$ dates are cannot be regarded as reliable.

\section{Other dating evidence}

Other evidence from the Phase 1 occupation is also relevant here. Fox and Green (1982: 72-73) reported that two adzes associated with this occupation were made from metasomatised argillite from the Ohana quarries on D'Urville Island. This is usually viewed as "early period" adze material and had previously been suggested as an additional line of evidence for the antiquity of the Phase 1 settlement (Green 1983: 112). These adzes have now 
been re-examined by Kath Prickett of Auckland Museum and her preliminary results largely invalidate this interpretation. While the adze illustrated in Fox and Green's (1982: 73) Figure 16 is confirmed as Nelson argillite, it is clearly a remnant of a much larger implement that has been reworked into the small 2B form typical of later periods. Such small argillite adzes are common well after AD 1500 and their presence has no particular chronological implications (Turner 2005: 61). Additionally, the adze illustrated in Figure 17 of Fox and Green (1982) is not argillite at all but a fossiliferous chert. This material is present in several local adze collections and Prickett believes is from a local Waikato source. Similarly, the chisel illustrated in Fox and Green's (1982) Figure 18 is made from a greywacke/meta-sandstone and also of likely local origin. Thus the artefacts which were once thought, on the basis of their raw material, to support an early date are, upon re-examination, found to either to be from local sources or, in the case of the sole argillite piece, to be a reworked from an older item. The assemblage as a whole does not indicate an early date for the site but is more typical of collections dated to later periods.

\section{DISCUSSION}

Open settlements without obvious defensive features, known in Māori as kainga, varied greatly in their size, spacing and distribution across the landscape, and only late in the post-contact period could some of them have been legitimately termed villages (Green 1990). A great many are described in field survey reports as composed of terraces with surface indications of subterranean pits which, whenever they are excavated, are found to cover a huge range of sizes and shapes. On occasion, some such sites have dwellings, earth ovens and extensive shellfish middens. Except in periods of serious conflict, these open settlements served as the everyday habitation sites for a local community. They may often have housed no more than an extended family unit and been occupied only seasonally for periods of as little as five years in light of shifting agriculture practices of Mãori.

In the Maioro site sequence Phase 1 begins with just such a small hamlet consisting of a series of subterranean storage pits along the top of a ridge and knoll. On the knoll portion of this ridgeline few structural features from Phase 1 remain, most having been obliterated by subsequent occupations. No reliable dates for this phase were obtained though no evidence was recovered by the excavators that pointed to a significant time gap between this and the succeeding phases (Fox and Green 1982: 76). We propose here that the first occupants of Maioro carved their initial settlement out of old growth forest dominated by trees with high inbuilt age. Wood from these trees would have been used as construction material at this time and we suggest charcoal from this source is likely to have supplied two of the dating 
samples. It is argued here that a more acceptable date for Phase 1 would be no earlier than the late 15 th century AD.

During the 16th century AD a second phase of occupation occurred with the knoll being converted to a small $p \bar{a}$ or defended food store. The principal form of defence was a steep scarp and a palisade of posts around the perimeter of the knoll, inside of which multiple small, often intercutting subterranean storage pits were constructed with roofs supported by a single row of small diameter uprights. These pits were tightly packed into the limited available space around two houses and a working floor ((Fox and Green 1882: Fig. 6). The whole arrangement seems to have been to protect the food crop and the hamlet's inhabitants during intermittent periods of conflict. The same pattern of occupancy seems to have been followed in Phase 3, tentatively dated to the late 16 th to early 17 th century AD.

$$
\text { *** }
$$

We argue that 12-13th century dates previously reported for Phase 1 at Maioro are probably biased by charcoal deriving from species such as Tötara that can contain wood with high inbuilt age. The evidence assembled here suggests that the combined old and new determinations for Phases 2 and 3 centres on the 16th century AD and that, in the absence of reliable dated samples from Phase 1, this occupation probably dates to no earlier than the 15 th century AD. Overall, we suggest Maioro was occupied by people practicing shifting agriculture for three fairly brief spells from the late 15 th to early 17 th century AD. If this chronological scheme is adopted, the Maioro sequence will fit comfortably within the broader patterns of North Island settlement and subsistence revealed by archaeological research, where intensive agricultural activities, inland settlement and fortified sites date from the 15th century AD onwards.

The Maioro reanalysis also shows the utility of considering the growth habitats and ecology of wood charcoal species in chronological interpretations. Though Püriri can grow to be a large and very long lived tree, its rather bushy form when growing outside closed canopy forests means it typically supplies posts with little significant inbuilt age. The practice of "chronometric hygiene" is problematic in assuming that all radiocarbon determinations on long-lived species are necessarily affected by in-built age, something which is clearly not the case with the Phase 2 and 3 samples from this site.

Lastly, the sequence outlined here of initial settlement in old growth forest dominated by trees with high inbuilt age, followed by later occupations in culturally modified landscapes dominated by secondary vegetation where the potential for inbuilt age in timber is substantially lessened, is likely 
common to many Polynesian islands. The implication is that the practice of "chronometric hygiene", where unidentified materials and/or long lived species are automatically eliminated from chronometric assessments, may have a more dramatic effect on dates from early period sites compared to those of later times, leading to biases in estimations of colonisation and other related processes.

\section{ACKNOWLEDGEMENTS}

Melinda Allen, Simon Bickler, Phil Moore, Kath Prickett and Marianne Turner have provided useful commentary during the drafting of this paper. Simon Bickler created Figure 1.

\section{NOTE}

This paper was drafted shortly before the death of Roger C. Green but was later significantly rewritten in response to a referee's report.

\section{REFERENCES}

Anderson, A., 1991. The chronology of colonization in New Zealand. Antiquity. 65: 767-95.

Davidson, Janet, B.F. Leach, M. Burtenshaw and G. Harris, 2007. Subterranean storage pits for kūmara (sweet potato, Ipomoea batatas L. Lam.): Ethnographic, archaeological and experimental research in New Zealand. New Zealand Journal of Archaeology, 28 [2006]: 5-49.

Dykgraaf, A.C., 1992. Princely puriri. New Zealand Geographic, 13: 102-17.

Dijkgraaf, A.C., 1994. Propagation and Timber Plantation Potential of Puriri (Vitex lucens). Unpublished MSc thesis, University of Auckland.

Fox, Aileen and R.C. Green, 1982. Excavations at Maioro, N51/5, South Auckland, 1965-66. Records of the Auckland Institute and Museum, 19: 53-80.

Green, R.C., 1983. Radiocarbon dates for Maioro, N51/5, South Auckland, 1965-66. Records of the Auckland Institute and Museum, 20: 107-14.

- 1990. The study of open settlements in New Zealand prehistory. In D.G. Sutton (ed.), The Archaeology of the Kainga. A study of Precontact Undefended settlements at Pouerua, Northland, New Zealand. Auckland: Auckland University Press, pp. 23-32.

Law, R.G., 2000. Pits long, large and prestigious: Recognition of varieties of Maori kümara storage pits in northern New Zealand. New Zealand Journal of Archaeology, 21 [1999]: 29-45.

McFadgen, B.G., 1982. Dating New Zealand archaeology by radiocarbon. New Zealand Journal of Science, 25: 379-92. 
Molloy B.P., C.J. Burrows, J.E. Cox, J.A. Johnston and P. Wardle, 1963. Distribution of subfossil forest remains, eastern South Island, New Zealand. New Zealand Journal of Botany, 1: 68-77.

Petchey, Fiona, A. Anderson, A. Hogg and A. Zondervan, 2008. The marine reservoir effect in the Southern Ocean: An evaluation of extant and new $\Delta \mathrm{R}$ and their application to archaeological chronologies. Journal of the Royal Society of New Zealand, 38(4): 243-62.

Schmidt, M.D., 1996. The commencement of pa construction in New Zealand prehistory. Journal of the Polynesian Society, 105(4): 441-60.

Turner, Marianne, 2005. Functional and technological explanations for the variation among early New Zealand adzes. New Zealand Journal of Archaeology, 26 (2004): 57-101.

Personal Communication:

Kath Prickett, Auckland War Memorial Museum, July 2009.

\begin{abstract}
As the two previously reported 12-13th century dates for the founding of the Maioro site have been controversial, residual charcoal from three previously dated samples was obtained and identified. Short lived material from one supplied a new AMS date so that there are now a total of five dates for Phases 2 and 3 whose overlapping ranges centre on the 16th century $\mathrm{AD}$. We suggest the two unexpectedly early dates attributed to Phase 1 are unreliable as they were run on unidentified charcoal that may have incorporated significant inbuilt ages. We argue occupations at this site may have begun no earlier than the late 15 th century AD and ended by the early 17th century AD. This analysis illustrates how the growth habitats and ecology of wood species used for dating can contribute to chronological interpretations and has implications for the practice of "chronometric hygiene".
\end{abstract}

Keywords: Maioro, $\mathrm{C}^{14}$ dating, charcoal, inbuilt age, chronometric hygiene 


\section{Ngā Mōteatea: An Introduction/He Kupu Arataki Jane McRae and Hēni Jacob}

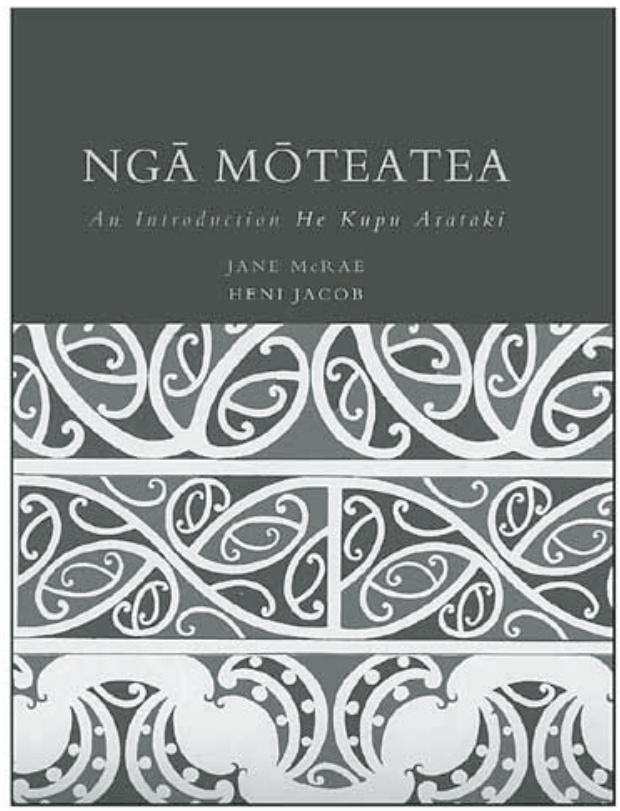

Mōteatea (sung laments) are at the heart of mātauranga Māori. They are the central strand of Māori poetry and song, a source of knowledge about tribal history and whakapapa, and a living art form. This book introduces Sir Apirana Ngata's classic four-volume collection of mōteatea, discussing the power and meaning of these traditional Māori songs. With dual text in English and Māori, and illustrated throughout, Ngā Mōteatea: An Introduction He Kupu Arataki provides an accessible entry point into a great Māori art form. 